\author{
V. Kucheruk ${ }^{1}$, P. Kulakov ${ }^{1}$, Yu. Moskvichova ${ }^{2}$, N. Gadzhula ${ }^{3}$, \\ P. Kissabekova ${ }^{4}$, A. Kulakova ${ }^{1}$, D. Karabekova ${ }^{4}$, A. Khassenov ${ }^{4}$ \\ ${ }^{l}$ Vinnytsia National Technical University, Ukraina; \\ ${ }^{2}$ Vinnytsia State Pedagogical University, Ukraine; \\ ${ }^{3}$ National Pirogov Memorial Medical University, Vinnytsia, Ukraine; \\ ${ }^{4}$ Ye.A. Buketov Karaganda State University, Kazakhstan \\ (E-mail: vladimir.kucheruk@gmail.com)
}

\title{
Development of the mathematical model of light flux intensity sensor based on the photodiode and operational amplifier
}

\begin{abstract}
The article describes a method for interpolating the dependence of the photodiode relative spectral sensitivity on the optical radiation wavelength using a special function that provides interpolation of the experimental dependence with any asymmetry coefficient. A new version of the light flux intensity sensor mathematical model based on a photodiode and an operational amplifier using the proposed interpolation technique has been created. It was found that the interpolation error does not exceed 3-6\%, depending on the type of photodiode and the shape of its experimentally obtained spectral characteristic. The processes occurring in the equivalent circuit of the measuring channel based on the operational amplifier are analyzed. The created mathematical model can be applied to optimize the processes in the measuring channel of the light flux intensity. The research results presented in the article can be used in the design and mathematical modeling of light flux intensity sensors for the needs of various fields of science, industry and medicine.
\end{abstract}

Keywords: sensor, photodiode, light flux intensity, spectral characteristic, mathematical model.

\section{Introduction}

Sensors are an integral part of most measuring instruments. The requirements for their accuracy, sensitivity, speed, and other parameters are constantly increasing. It is worth noting that the accuracy of many measuring instruments is very often determined by the accuracy of the sensor, since modern secondary measuring conversion means have a small error compared to sensors.

Optical photoelectric sensors are currently widely distributed and are used in various fields of science and technology. For example, in dentistry, optical sensors are used for stomatoscopy and photoscopy [1-3]. Photoelectric sensors of angular position are used for measuring the rotational parameters of various objects $[4,5]$. In order to identify the water content in milk, enterprises use specialized cheking means based on photoelectric sensors of the light flux intensity [6-8].

The principle of optical sensors operation is based on the dependence of the optical radiation parameters on the value of the physical parameter that is being measured. The measured physical parameter can act directly on the radiation source, changing its intensity or affecting the parameters of the optical flux. Photoelectric sensors convert the optical parameters of the light flux into an electrical signal.

The article aim is the further development of the theory and practice of the design, analysis and mathematical modeling of the photoelectric sensors, which provide a light flux intensity measuring conversion to a constant voltage.

\section{Formulation of the problem}

In accordance with [9-11], the nature of the photodiode spectral characteristic depends on a large number of factors, and its physical analysis is not possible. It is important to find a function suitable for its mathematical description. From an analysis of the technical documentation of optoelectronic components manufacturers [12-16], it follows that the spectral characteristic of the photodiode is bell-shaped, equal to zero at certain wavelengths, can be symmetric and asymmetric, and the asymmetry coefficient can be less and more than zero.

In $[4,7]$, mathematical models of a light flux intensity sensor based on a photodiode and an operational amplifier are considered. In these mathematical models, the spectral characteristic of the photodiode - the dependence of its integral current sensitivity on the optical radiation wavelength, is not taken into account. 
Therefore, the improvement of the existing mathematical model in this direction is an important task, the solution of which will improve the adequacy of modeling and accuracy of calculation of photoelectric sensors and measuring instruments based on them.

\section{Research results}

It is proposed to look for a function that interpolates the spectral characteristic of a photodiode in the form [17]

$$
g(x)=x^{a-1}(1-x)^{b-1},
$$

where $a, b$ - numerical parameters of the function, the relationship between them depends on the asymmetry of the function graph.

If $a>b$, the asymmetry coefficient is less than zero and the function maximum is shifted to the left, if $a<b$, the asymmetry coefficient is greater than zero and the function maximum is shifted to the right. If $a=b \neq 1$, then the function is symmetric, if $a=1$ and $b=1$, then the graph of the function is a direct line. The value of function (1) is zero if $x=0$, or $x=1$. Then, the function (1) can be taken as the basis for finding the interpolating function of the photodiode spectral characteristic.

Express the variable $x$ as

$$
x=\frac{\lambda}{\lambda_{M A X}},
$$

where $\lambda-$ is the wavelength of the optical radiation; $\lambda_{M A X}-$ the maximum wavelength of optical radiation at which the value of the spectral sensitivity is zero.

The interpolating function of the photodiode spectral characteristic can be presented as

$$
S_{I 0}(\lambda)=K_{A}\left(\frac{\lambda}{\lambda_{M A X}}\right)^{a-1}\left(1-\frac{\lambda}{\lambda_{M A X}}\right)^{b-1},
$$

where $K_{A}-$ is the coefficient of proportionality between function (1) and the value of the photodiode spectral sensitivity.

In order to find the analytic formula of the spectral characteristic interpolating function, it is necessary to find the coefficient $K_{A}$ and parameters $a$ and $b$. In order to find the value of $\lambda_{0}$, at which function (3) reaches its maximum. To do this, we should define the first derivative of function (3) and equate it to zero.

$$
S_{I 0}^{\prime}(\lambda)=(a-1)\left(1-\frac{\lambda}{\lambda_{M A X}}\right)^{b-1}\left(\frac{\lambda}{\lambda_{M A X}}\right)^{a-2}-(b-1)\left(1-\frac{\lambda}{\lambda_{M A X}}\right)^{b-2}\left(\frac{\lambda}{\lambda_{M A X}}\right)^{a-1}=0 .
$$

As a result of solving equation (4), we obtain the wavelength of optical radiation at which the photodiode spectral characteristic reaches a maximum

$$
\lambda_{0}=\frac{\lambda_{M A X}}{1+\frac{b-1}{a-1}} .
$$

From formula (5), after transformations, we obtain

$$
b=\left(\frac{\lambda_{M A X}}{\lambda_{0}}-1\right)(a-1)+1 .
$$

Substituting (6) into (3), we obtain the maximum value of the photodiode spectral characteristic

$$
S_{I 0}\left(\lambda_{0}\right)=K_{A}\left(\frac{\lambda_{0}}{\lambda_{M A X}}\right)^{(a-1)}\left(1-\frac{\lambda_{0}}{\lambda_{M A X}}\right)^{\left(\frac{\lambda_{M A X}}{\lambda_{0}}-1\right)(a-1)} .
$$

From (7) we find the formula that determines the coefficient $K_{A}$

$$
K_{A}=S_{I 0}\left(\lambda_{0}\right)\left(\frac{\lambda_{0}}{\lambda_{M A X}}\right)^{(1-a)}\left(1-\frac{\lambda_{0}}{\lambda_{M A X}}\right)^{\left(\frac{\lambda_{M A X}}{\lambda_{0}}-1\right)(1-a)} .
$$

The experimental spectral characteristics of photodiodes, which are given in the technical documentation, are obtained in a certain range of optical radiation wavelengths from $\lambda_{M I N}$ to $\lambda_{M A X}[12-16]$. At wave- 
length $\lambda_{M I N}$, the spectral characteristic value can be either zero or zero. The value of the interpolating function at wavelength $\lambda_{M I N}$ is determined by the formula

$$
S_{I 0}\left(\lambda_{M I N}\right)=K_{A}\left(\frac{\lambda_{M I N}}{\lambda_{M A X}}\right)^{(a-1)}\left(1-\frac{\lambda_{M I N}}{\lambda_{M A X}}\right)^{\left(\frac{\lambda_{M A X}}{\lambda_{0}}-1\right)(a-1)} .
$$

From the formula (9), that determines the coefficient $K_{A}$, we obtain

$$
K_{A}=S_{I 0}\left(\lambda_{M I N}\right)\left(\frac{\lambda_{M I N}}{\lambda_{M A X}}\right)^{(1-a)}\left(1-\frac{\lambda_{M I N}}{\lambda_{M A X}}\right)^{\left(\frac{\lambda_{M A X}}{\lambda_{0}}-1\right)(1-a)}
$$

Equate the right parts of formula (8) and (10)

$$
S_{I 0}\left(\lambda_{0}\right)\left(\left(\frac{\lambda_{0}}{\lambda_{M A X}}\right)\left(1-\frac{\lambda_{0}}{\lambda_{M A X}}\right)^{\frac{\lambda_{M A X}}{\lambda_{0}}-1}\right)^{1-a}=S_{I 0}\left(\lambda_{M I N}\right)\left(\left(\frac{\lambda_{M I N}}{\lambda_{M A X}}\right)\left(1-\frac{\lambda_{M I N}}{\lambda_{M A X}}\right)^{\frac{\lambda_{M A X}}{\lambda_{0}}-1}\right)^{1-a} .
$$

As a result of solving equation (11), we get a formula that determines the parameter $a$ value

$$
a=1-\frac{1}{\log _{\frac{S_{I 0}\left(\lambda_{0}\right)}{S_{I 0}\left(\lambda_{M N}\right)}} \frac{\lambda_{M I N}}{\lambda_{0}}\left(\frac{\lambda_{M A X}-\lambda_{M I N}}{\lambda_{M A X}-\lambda_{0}}\right)^{\frac{\lambda_{M A X}-1}{\lambda_{0}}} .}
$$

The parameters $\lambda_{M A X}, \lambda_{M I N}, \lambda_{0}, S_{I 0}\left(\lambda_{M I N}\right)$, and $S_{I 0}\left(\lambda_{0}\right)$ are determined by the experimental spectral characteristic of the photodiode. By substituting the parameter $a$ calculated by formula (12), to the formula (6), the value of the parameter $b$ is determined. Then, using (10) or (8), the value of $K_{A}$ is calculated.

The generalized formula for a function that interpolates the photodiode spectral characteristic is obtained by substituting the formulas (12), (6), and (8) to (3).

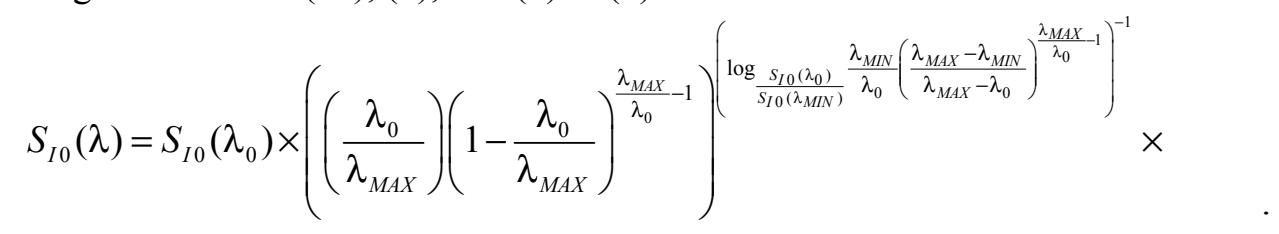

$$
\begin{aligned}
& \times\left(\frac{\lambda}{\lambda_{M A X}}\right)^{-\left(\log _{\frac{S_{I 0}\left(\lambda_{0}\right)}{S_{I 0}\left(\lambda_{M N}\right)}} \frac{\lambda_{M I N}}{\lambda_{0}}\left(\frac{\lambda_{M A X}-\lambda_{M I N}}{\lambda_{M A X}-\lambda_{0}}\right)^{\frac{\lambda_{M A X}}{\lambda_{0}}}\right)^{-1}} \times\left(1-\frac{\lambda}{\lambda_{M A X}}\right)^{-\left(\frac{\lambda_{M A X}}{\lambda_{0}}-1\right)\left(\log _{\frac{S_{I 0}\left(\lambda_{0}\right)}{S_{I 0}\left(\lambda_{M N}\right)}} \frac{\lambda_{M I N}}{\lambda_{0}}\left(\frac{\lambda_{M A X}-\lambda_{M I N}}{\lambda_{M A X}-\lambda_{0}}\right)^{\frac{\lambda_{M A X}}{\lambda_{0}}-1}\right)^{-1}} .
\end{aligned}
$$

The interpolating function of the relative spectral photodiode sensitivity is defined as the ratio of the function $S_{I 0}(\lambda)$ to its maximum value $S_{I 0}\left(\lambda_{0}\right)$, expressed as a percentage

$$
S_{R}(\lambda)=\frac{S_{I 0}(\lambda)}{S_{I 0}\left(\lambda_{0}\right)} \cdot 100 \%
$$

The typical experimental depedence of the relative spectral photodiode sensitivity on the optical radiation wavelength, and the corresponding depedence of the interpolating function $S_{R}(\lambda)$ are shown on the Figure 1.

The experimental dependence on the Figure 1 corresponds to the photodiode S1336-18BQ manufactured by Hamamatsu Photonics, whose spectral characteristics has a maximum at a wavelength of $960 \mathrm{~nm}$ [15]. As a result of the conducted research, it is established that the interpolation error does not exceed 3$6 \%$ depending on the type of photodiode and form of its experimentally obtained spectral characteristic.

The above results were obtained using the Maple 9 mathematical software package [18]. 


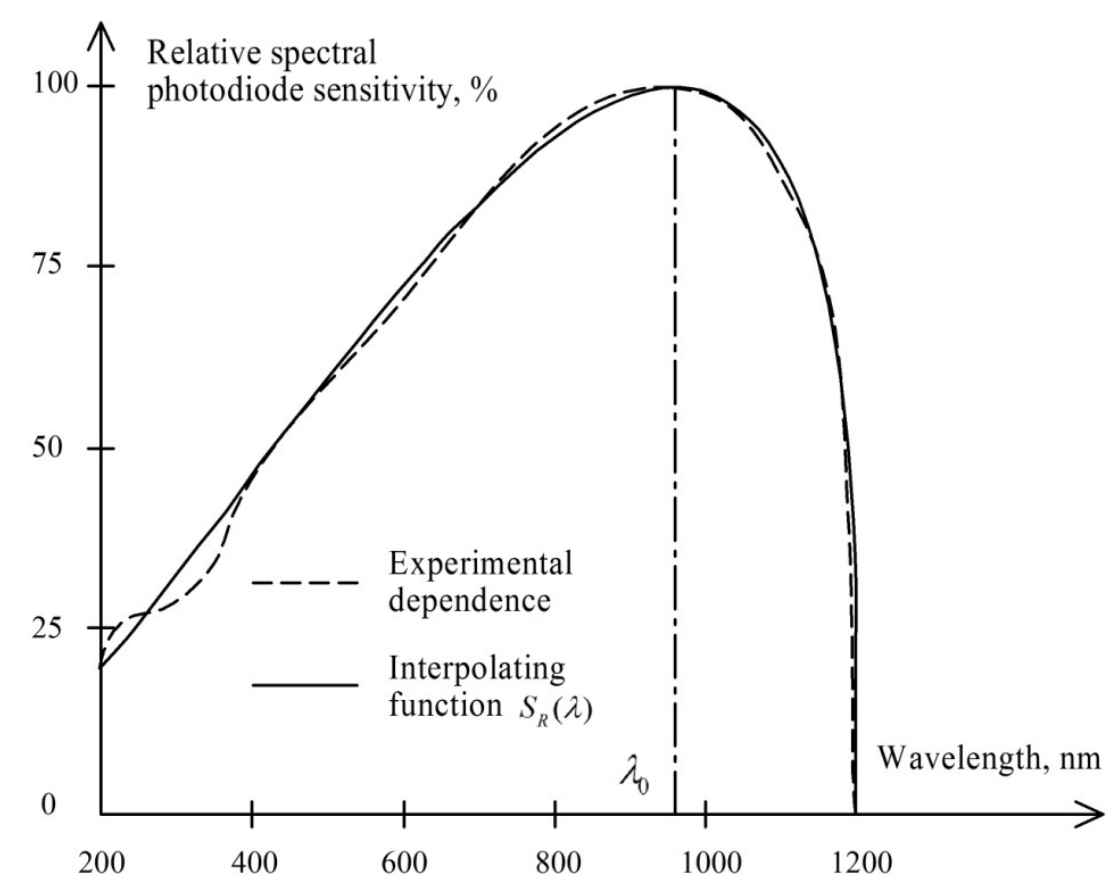

Figure 1. The typical experimental depedence of the relative spectral photodiode sensitivity on the optical radiation wavelength, and the corresponding depedence of the interpolating function

The electrical scheme of a light flux intensity sensor based on a photodiode and operational amplifier is shown on the Figure $2 a$, and is its equivalent scheme is shown on the Figure $2 b$.

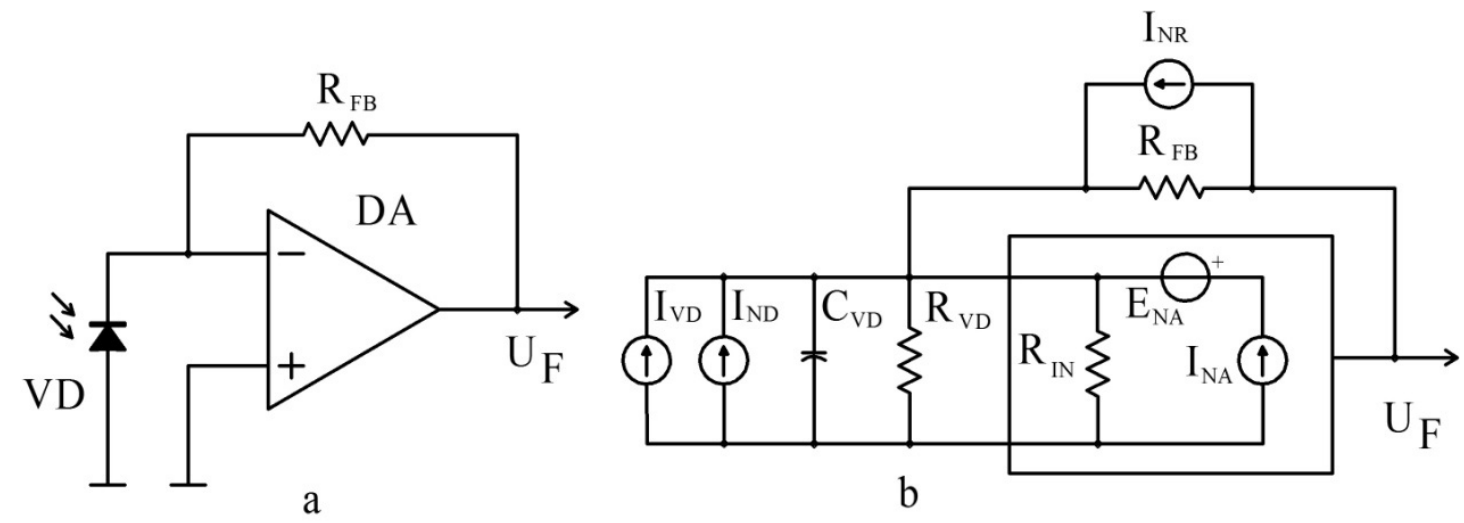

Figure 2. Light flux intensity sensor based on the photodiode and operational amplifier

The dependence of the current flowing through the photodiode on the radiation flux is described by the formula [19]

$$
I_{V D}=\frac{\Phi S_{I 0}(\lambda)}{\sqrt{1+\left(\Omega \tau_{V D}\right)^{2}}}-I_{S}\left(\exp \left(\frac{e U_{V D}}{k T}\right)-1\right),
$$

where $I_{V D}$ - photodiode current; $F-$ radiation flux; $I_{S}$ - dark current of the photodiode; $U_{V D}$ - voltage drop on the photodiode; $T$ - absolute temperature; $k$ - Boltzmann's constant; $e$ - charge of electron; $\Omega$ - flux radiation modulation cyclic frequency; $\tau_{V D}$ - the photodiode time constant, which depends on the values of the photodiode internal resistance $R_{V D}$ and the photodiode parasitic capacitance $C_{V D}$.

When using a light source with a condenser lens, it is possible to obtain a flat-parallel radiation flux that is the same throughout the whole plane. In this case, the radiation flux and the area of the photodiode photosensitive layer which is radiated, are related by the ratio [20]

$$
\Phi=I(\lambda) \cdot S
$$


where $I(\lambda) \quad$ - the intensity of the radiation flux which, when using any light source, is a function of the wavelength $\lambda ; S$ - the area of the photodiode photosensitive layer which is radiated.

The output voltage of the flow flux sensor based on the photodiode and the operational amplifier, taking into account the zero offset, the difference of the input currents, and the noise voltage, is described by the formula [19]

$$
U_{F}=\frac{I_{V D} R_{F B}}{1+\frac{R_{F B}}{K_{0} R_{I N}}+\frac{1}{K_{0}}}+\Delta I R_{F B}+U_{O F}+U_{N},
$$

where $K_{0}$ - operational amplifier gain without feedback; $R_{I N}$ - input resistance of operational amplifier; $U_{O F}$ - operational amplifier zero offset voltage; $\Delta I$ - the difference of the operational amplifier input currents; $R_{F B}$ - resistance in the operational amplifier feedback loop; $U_{N}$ - noise voltage at the operational amplifier output.

The noise current density of the feedback resistance [19] is determined by the formula

$$
I_{N R}=\sqrt{\frac{4 k T \Delta f}{R_{F B}}}
$$

where $\Delta f$ - effective bandwidth of the operational amplifier. formula

The noise current density of a photodiode operating in a photovoltaic mode [19] is determined by the

$$
I_{N D}=\sqrt{\frac{4 k T \Delta f}{R_{V D}}} .
$$

The noise output voltage module is determined by the formula [19]

$$
U_{N}=\sqrt{E_{N A}^{2}+\left(I_{N A}^{2}+I_{N D}^{2}+I_{N R}^{2}\right) R_{F B}},
$$

where $I_{N A}$ - operational amplifier noise current; $E_{N A}$ - operational amplifier noise voltage.

Substituting (13), (15), (16), (18), (19), (20) into (17), after transformations, we obtain a formula that determines the dependence of the output voltage of the photoelectric light flux intensity sensor, from the wavelength of the optical radiation.

$$
\begin{aligned}
& U_{F}(\lambda)=\left(S_{I 0}\left(\lambda_{0}\right) \times\left(\left(\frac{\lambda_{0}}{\lambda_{M A X}}\right)\left(1-\frac{\lambda_{0}}{\lambda_{M A X}}\right)^{\frac{\lambda_{M A X}}{\lambda_{0}}-1}\right)^{\left.\log _{\frac{S_{I}\left(\lambda_{0}\right)}{S_{I}\left(\lambda_{M N}\right)}} \frac{\lambda_{M I N}}{\lambda_{0}}\left(\frac{\lambda_{M A X}-\lambda_{M I N}}{\lambda_{M A X}-\lambda_{0}}\right)^{\frac{\lambda_{M A X}-1}{\lambda_{0}}}\right)^{-1}} \times\right.
\end{aligned}
$$

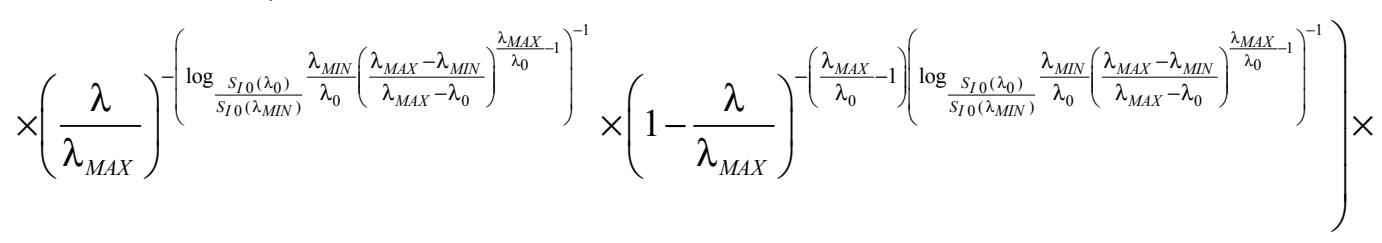

$$
\begin{aligned}
& \times \frac{R_{F B} S}{\left(1+\frac{R_{F B}}{K_{0} R_{I N}}+\frac{1}{K_{0}}\right) \sqrt{1+\left(\Omega \tau_{V D}\right)^{2}}} I(\lambda)-\frac{I_{S} R_{F B}\left(\exp \left(\frac{e U_{V D}}{k T}\right)-1\right)}{1+\frac{R_{F B}}{K_{0} R_{I N}}+\frac{1}{K_{0}}}+\Delta I R_{F B}+U_{O F}+ \\
& +\sqrt{E_{N A}^{2}+\left(I_{N A}^{2}+\frac{4 k T \Delta f}{R_{V D}}+\frac{4 k T \Delta f}{R_{F B}}\right) R_{F B}} .
\end{aligned}
$$

Denote by $\lambda_{1}$ and $\lambda_{2}$, the lower and upper boundary wavelengths of the spectral characteristics of the optical radiation source. Then the output voltage of the light intensity sensor based on the photodiode and the operational amplifier, subject to a constant value of the spectral density of the light source, is determined by the formula 


$$
\begin{aligned}
& U_{F}=\int_{\lambda_{1}}^{\lambda_{2}}\left(S_{I 0}\left(\lambda_{0}\right) \times\left(\left(\frac{\lambda_{0}}{\lambda_{M A X}}\right)\left(1-\frac{\lambda_{0}}{\lambda_{M A X}}\right)^{\frac{\lambda_{M A X}}{\lambda_{0}}-1}\right)^{\left.\log \frac{S_{I 0}\left(\lambda_{0}\right)}{S_{I 0}\left(\lambda_{M N N}\right)} \frac{\lambda_{M I N}}{\lambda_{0}}\left(\frac{\lambda_{M A X}-\lambda_{M I N}}{\lambda_{M A X}-\lambda_{0}}\right)^{\frac{\lambda_{M A X}}{\lambda_{0}}-1}\right)^{-1}} \times\right.
\end{aligned}
$$

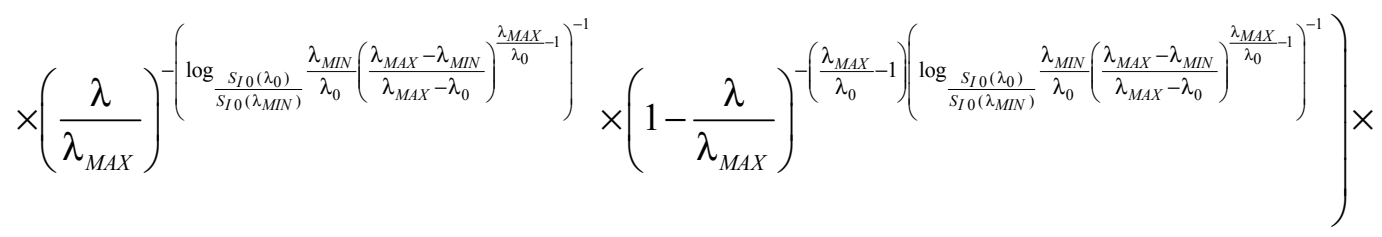

$$
\begin{aligned}
& \times \frac{R_{F B} S}{\left(1+\frac{R_{F B}}{K_{0} R_{I N}}+\frac{1}{K_{0}}\right) \sqrt{1+\left(\Omega \tau_{V D}\right)^{2}}} I(\lambda) d \lambda-\frac{I_{S} R_{F B}\left(\exp \left(\frac{e U_{V D}}{k T}\right)-1\right)}{1+\frac{R_{F B}}{K_{0} R_{I N}}+\frac{1}{K_{0}}}+\Delta I R_{F B}+U_{O F}+ \\
& +\sqrt{E_{N A}^{2}+\left(I_{N A}^{2}+\frac{4 k T \Delta f}{R_{V D}}+\frac{4 k T \Delta f}{R_{F B}}\right) R_{F B}} .
\end{aligned}
$$

Formula (21) is a mathematical model of the light flux intensity sensor based on a photodiode and an operational amplifier, which takes into account the dependence of the photodiode spectral sensitivity on the wavelength of the optical radiation.

\section{Conclusions}

As a result of the conducted researches the universal method of interpolation of the photodiode spectral sensitivity dependence on the optical radiation wavelength is proposed. By using the obtained interpolating function, the known mathematical model of the light flux intensity sensor based on the photodiode and the operational amplifier is improved. On the basis of the conducted research, it is established that the interpolation error does not exceed 3-6\% depending on the type of photodiode and form of its experimentally obtained spectral characteristic. Thus, the advanced mathematical model allows to increase the adequacy of modeling and the accuracy of photoelectric sensors calculation as well as measuring devices based on them.

\section{References}

1 Krikheli N.I. Results of autofluorescence somatoscope lichen planus as a screening method for detecting precancerous and cancerous changes of the oral mucosa / N.I. Krikheli, T.I. Pozdnyakova, N.N. Bulgakova, E.Yu. Prokudina // Russian Stomatology. - 2016. - Vol. 9, No. 4. - P. 13-17.

2 Редуто К.В. Оптические методы исследований в стоматологии / К.В. Редуто, Л.А. Казеко // Современная стоматология. - 2013. - № 1. - С. 13-16.

3 Межевикина Г.С. Современные методы диагностики предраковых и раковых изменений слизистой оболочки рта / Г.С. Межевикина, Е.А. Глухова // Наука молодых (Eruditio Juvenium). — 2018. — T. 6, № 4. — С. 600-606.

4 Podzharenko V.A. Photoelectric angle converter: Selected papers from the international conference on optoelectronic information technologies / V.A. Podzharenko, P.I. Kulakov // International conference on optoelectronic information technologies. Vinnitsa, Ukraine: VSTU, 2001. — Vol. 4425. — P. 452-456. DOI: 10.1117/12.429768.

5 Kucheruk V.Yu. Computer-measuring system of the induction motor's dynamical torque-speed characteristics / V.Yu. Kucheruk, I.P. Kurytnik, Ye.Z. Oshanov, P.I. Kulakov, A.A. Semenov, D.Zh. Karabekova, A.K. Khassenov // Bulletin of the Karaganda University. Physics series. - 2019. - No. 2(94). - P. 92-100.

6 Kucheruk V. Measurement of the Number Servings of Milk and Control of Water Content in Milk on Stall Milking Machines / V. Kucheruk, P. Kulakov, N. Storozhuk // Proceedings of the International Conference SCIT 2016. - May 20-21. - 2016. Warsawa, Poland. Recent Advances in Systems, Control and Information Technology. - P. V. - Vol. 543 of the series «Advances in Intelligent Systems and Computing». - P. 435-447. — 01 December 2016. DOI: 10.1007/978-3-319-48923-0_46.

7 Kucheruk V. Mathematical model of the visible range optical radiation passing through a water-milk solution / V. Kucheruk, I.P. Kurytnik, P. Kulakov, A.N. Vasilevskyi, D.Zh. Karabekova, D. Mostovyi, A. Kulakova // Bulletin of the Karaganda University. Physics series. - 2018. - No. 1(89). - P. 24-31.

8 Kucheruk V. Optical method to determine the quantity of water in milk using the visible radiation range / V. Kucheruk, P. Kulakov, O. Vasilevskyi, D. Mostovyi, A. Kulakova, I.M. Kobylyanska, G. Karnakova, P. Kisala // Photonics Applications in Astronomy, Communications, Industry, and High Energy Physics Experiments 2018, https://doi.org/10.1117/12.2501605 
9 Graham B. Introduction to Sensors for Ranging and Imaging / B. Graham. — SciTech Publishing, 2009. — 744 p.

10 Ишанин Г.Г. Источники и приемники излучения: учеб. пос. / Г.Г. Ишанин, Э.Д. Панков, Х.Л. Андреев, Г.В. Подыциигом. - СПб.: Политехника, 1991. - 240 с.

11 Knoll F.G. Radiation detection and measurement: 4th ed. / F.G. Knoll. — Wiley, 2010. — 298 p.

12 Everlight Americas Inc. — [Electronic resource]. — Access: http://everlightamericas.com.

13 Infineon Technologies AG. — [Electronic resource]. - Access: https://www.infineon.com.

14 OPTEK — TT electronics Company — [Electronic resource]. — Access: http://optekinc.com.

15 Hamamatsu Photonics. - [Electronic resource] — Access: http://www.hamamatsu.com.

16 AMS-TAOS USA Inc. — [Electronic resource]. - Access: http://www.taosinc.com.

17 Абрамовиц М. Справочник по специальным функциям / М. Абрамовиц, И. Стиган. — М.: Наука, 1979. — 832 с.

18 Official web site of Maple's software developer - [Electronic resource]. - Access mode: http://www.maplesoft.com (Serial Number IS: 917995808).

19 Аксененко М.Д. Микроэлектронные фотоприемные устройства / М.Д. Аксененко, М.Л. Бараночников, В. Смолин. М.: Энергоатомиздат, 1984. - $208 \mathrm{c.}$

20 Кузьмичев В.Е. Законы и формулы физики: сб. / В.Е. Кузьмичев. — Киев: Наук. думка, 1989. — 864 с.

В. Кучерук, П. Кулаков, И. Москвичова, Г. Гаджула, П. Кисабекова, А. Кулакова, Д. Карабекова, А. Хасенов

\title{
Фотодиод және операциялық күшейткіштің негізінде жарық ағынының қарқындылық датчигінің математикалық моделін әзірлеу
}

\begin{abstract}
Мақалада фотодиодтың салыстырмалы спектрлік сезімталдығының оптикалық сәулеленудің толқын ұзындығына тәуелділігін эксперименттік тәуелділікті кез-келген асимметрия коэффициентімен интерполяциялайтын арнайы функцияны қолдану арқылы интерполяция әдісі ұсынылған. Ұсынылған интерполяция әдісімен фотодиод пен жұмыс күшейткішіне негізделген жарық ағынының қарқындылығы сенсорының математикалық моделінің жаңа нұсқасы жасалған. Интерполяция қателігі фотодиодтың түріне және оның эксперименталды түрде алынған спектрлік сипаттамасына байланысты 3-6\%-дан аспайтыны анықталды. Жұмыс күшейткіші негізінде өлшеу арнасының эквивалентті тізбегінде болатын процестер талданған. Жасалған математикалық модель жарық ағынының қарқындылығын өлшеу каналындағы процестерді оңтайландыру үшін қолдануға болады. Мақалада келтірілген зерттеу нәтижелері ғылымның, өнеркәсіптің және медицинаның әртүрлі салаларының қажеттіліктері үшін жарық ағынының қарқындылығы датчиктерін жобалау мен математикалық модельдеуде қолданыла алады.
\end{abstract}

Кілm сөздер: сенсор, фотодиод, жарық ағынының қарқындылығы, спектралды сипаттама, математикалық модель.

В. Кучерук, П. Кулаков, Ю. Москвичова, Г. Гаджула, П. Кисабекова, А. Кулакова, Д. Карабекова, А. Хасенов

\section{Разработка математической модели датчика интенсивности светового потока на основе фотодиода и операционного усилителя}

\begin{abstract}
В статье предложена методика интерполяции зависимости относительной спектральной чувствительности фотодиода от длины волны оптического излучения с помощью специальной функции, которая обеспечивает интерполяцию экспериментальной зависимости с любым коэффициентом асимметрии. Создан новый вариант математической модели сенсора интенсивности светового потока на основе фотодиода и операционного усилителя с использованием предложенной методики интерполяции. Установлено, что ошибка интерполяции не превышает 3-6 \%, в зависимости от типа фотодиода и формы его экспериментально полученной спектральной характеристики. Проанализированы процессы, протекающие в эквивалентной схеме измерительного канала на основе операционного усилителя. Созданная математическая модель может быть применена для оптимизации процессов в измерительном канале интенсивности светового потока. Результаты исследования, приведенные в статье, могут быть использованы при проектировании и математическом моделировании сенсоров интенсивности светового потока для нужд различных областей науки, промышленности и медицины.
\end{abstract}

Ключевые слова: сенсор, фотодиод, интенсивность светового потока, спектральная характеристика, математическая модель. 


\section{References}

1 Krikheli, N.I., Pozdnyakova, T.I., Bulgakova, N.N., \& Prokudina, E.Yu. (2016). Results of autofluorescence somatoscope lichen planus as a screening method for detecting precancerous and cancerous changes of the oral mucosa. Russian Stomatology, 9, 4, $13-17$.

2 Reduto, K.V., \& Kazeko, L.A. (2013). Opticheskie metody issledovanii v stomatolohii [Optical methods of research in dentistry]. Sovremennaia stomatolohiia - Modern Dentistry, 1, 13-16 [in Russian].

3 Mezhevikina, G.S., \& Glukhova, E.A. (2018). Sovremennye metody diahnostiki predrakovykh i rakovykh izmenenii slizistoi obolochki rta 「Modern diagnostic methods precancerous and cancerous changes of the oral mucosa]. Nauka molodykh - Science of the young, 6, 4, 600-606 [in Russian].

4 Podzharenko, V.A., \& Kulakov, P.I. (2001). Photoelectric angle converter: Selected papers from the international conference on optoelectronic information technologies. International conference on optoelectronic information technologies, 4425, 452-456. DOI: $10.1117 / 12.429768$.

5 Kucheruk, V.Yu., Kurytnik, I.P., Oshanov, Ye.Z., Kulakov, P.I., Semenov, A.A., Karabekova, D.Zh., \& Khassenov, A.K. (2019). Computer-measuring system of the induction motor's dynamical torque-speed characteristics. Bulletin of the Karaganda University. «Physics» series, 2(94), 92-100.

6 Kucheruk, V., Kulakov, P., \& Storozhuk, N. (2016). Measurement of the Number Servings of Milk and Control of Water Content in Milk on Stall Milking Machines. Proceedings of the International Conference SCIT 2016, May 20-21, 2016, Warsaw, Poland. Recent Advances in Systems, Control and Information Technology. Part V, Volume 543 of the series Advances in Intelligent Systems and Computing. (pp. 435-447). 01 December 2016. DOI: 10.1007/978-3-319-48923-0_46.

7 Kucheruk, V., Kurytnik, I.P., Kulakov, P., Vasilevskyi, A.N., Karabekova, D.Zh., Mostovyi, D., \& Kulakova, A. (2018). Mathematical model of the visible range optical radiation passing through a water-milk solution. Bulletin of the Karaganda University. «Physics» series, 1(89), 24-31.

8 Kucheruk, V., Kulakov, P., Vasilevskyi, O., Mostovyi, D., Kulakova, A., \& Kobylyanska, I.M., et al. (2018). Optical method to determine the quantity of water in milk using the visible radiation range. Photonics Applications in Astronomy, Communications, Industry, and High Energy Physics Experiments 2018, https://doi.org/10.1117/12.2501605

9 Graham, B. (2009). Introduction to Sensors for Ranging and Imaging. SciTech Publishing.

10 Ishanin, G., Pankov, E., Andreev, A., \& Polschykov, G. (1991). Istochniki i priemniki izlucheniia [Sources and receiver of radiation]. Saint-Petersburg: Politekhnika [in Russian].

11 Knoll, F.G. (2010). Radiation detection and measurement: 4th ed., Wiley.

12 Everlight Americas Inc. (n.d.). everlightamericas.com Retrieved from http://everlightamericas.com.

13 Infineon Technologies AG. (n.d.). www.infineon.com Retrieved from https://www.infineon.com.

14 OPTEK - TT electronics Company. (n.d.). optekinc.com Retrieved from http://optekinc.com.

15 Hamamatsu Photonics. (n.d.). www.hamamatsu.com Retrieved from http://www.hamamatsu.com.

16 AMS-TAOS USA Inc. (n.d.). www.taosinc.com Retrieved from http://www.taosinc.com.

17 Abramovits, M., \& Stigan, I. (1979). Spravochnik po spetsialnym funktsiiam [Reference for special functions]. Moscow: Nauka [in Russian].

18 Official web site of Maple's software developer. (n.d.). www.maplesoft.com Retrieved from http://www.maplesoft.com (Serial number is: 917995808).

19 Aksenenko, M.D., Baranochnikov, M., \& Smolin, A. (1984). Mikroelektronnye fotopriemnye ustroistva [Microelectronic photodetector devices]. Moscow: Enerhoatomizdat [in Russian].

20 Kuzmichev, V.E. (1989). Zakony i formuly fiziki [Laws of physics and the formula]. Kiev: Naukova Dumka [in Russian]. 